\title{
INITIATIVES AND ACTIVITIES FOR THE DEVELOPMENT OF INTERMODAL FREIGHT TRANSPORT IN SLOVENIA
}

\author{
Marina Zanne ${ }^{1}$, Bojan Beškovnik ${ }^{2}$ \\ 1,2 University of Ljubljana, Faculty of Maritime Studies and Transport, Slovenia
}

Received 08 March 2019; accepted 03 April 2019

\begin{abstract}
European Union (EU) has a strong focus on developing intermodal transport as a solution to slow down the growth of unimodal road freight transport. Different strategies and approaches have been undertaken by the EU, where the modernization of railway infrastructure and service standardization step out. At the same time, also the national governments have a significant role in promoting and encouraging the use of intermodal transport. In this paper, the authors provide an overview of intermodal transport development in Slovenia. They assess different national measures and programmes that can be applied, in order to support the intermodal transport, and investigate the application of these measures. To conclude, they create a list of suggestions on future activities for promotion of intermodal transport in Slovenia, in order to support EU and primarily central European region's expectations for the use of southern maritime European transport route and the two core network corridors.
\end{abstract}

Keywords: intermodal freight transport, intermodal corridors, intermodal connectivity, EU initiatives, national measures.

\section{Introduction}

Freight transport presents an important element in the development of the economy and the society, but the growth of freight flows is becoming challenging. The overall demand for freight transport in Europe is constantly growing; based on the available data the total intra-European (EU 28) freight flows increased by $12.8 \%$ in the period from 2000 to 2016 . This is less than the growth of gross domestic products (GDP) at 2005 prices was in the same period (around 20.8\% in total), which is good; however, it is not good that the freight flows are increasing much faster on roads than in any other transport mode, resulting in a growing share of road freight transport in modal split. In fact, the share of transport work (in tonkilometres) done on roads increased from $46.5 \%$ in 2000 to $49.3 \%$ in 2016 , while the rails lost $1.3 \%$ in share to drop to modest $11.2 \%$ (EC, 2018). The existence of empty rides of road freight vehicles makes these numbers even worse; around $20 \%$ of trucks run empty while partially loaded vehicles are also very common (Transport \& Environment, 2017).

The main goal of the EU transport policy is to achieve an economically efficient transport that is at the same time safe and green. One of the solutions to reach this goal is by enhancing the use of intermodal

\footnotetext{
${ }^{1}$ Corresponding author: marina.zanne@fpp.uni-lj.si
} 
transport, where rail, inland waterways or sea are used for long-distance transport while first and last mile delivery are done by the road transport, in order to provide flexibility in door-delivery services (Bergqvist \& Behrends, 2011). Intermodal transport, either accompanied (road vehicles) or unaccompanied (semi-trailers, containers and swap bodies) can provide several benefits, like for example lower transport costs, shorter transit times (not always achievable), reduced consumption of fossil fuels and last but not less it can remove freight vehicles from roads.

In this paper, the authors present an overview of intermodal transport development in Slovenia with the assessment of different national measures and programmes that can be applied to support the intermodal transport, and investigate the application of these measures in Slovenia. They create a list of suggestions on future activities for promotion of intermodal transport in Slovenia, in order to support more intensified use of the southern maritime European transport route.

\section{Intermodal Transport in EU and Slovenia}

The beginnings of intermodal transport in Europe date back to the late 1960s when some European railways had a vision of developing combined road-rail freight transport of unified loads, where the rail should have the priority on longer transport routes and the road transport should be used just on shortest possible distances (Seidelmann, 2010; Bektas \& Crainic, 2007).
The intermodal rail transport is gaining importance in EU. In the period from 1992 when Directive on combined transport was written to 2014 when the external study on the achievements of combined transport was done, a 2.5 trillion tonne-kilometres were shifted from roads, and intermodal transport achieved savings of 2.1 billion EUR in 2011 alone (EC, 2016). According to Report on combined transport (UIC, 2019), 253.4 million tons of cargo were transported in accompanied or unaccompanied intermodal rail transport in 2017, almost $10 \%$ more than in 2015 . The share of intermodal rail freight in total rail freight is now around $22 \%$, and is having a growing trend. However, the share of rail transport in total is declining (Eurostat, 2019).

Intermodal rail freight transport has been in use in Slovenia since 1974, with the first "piggy-back" trains connecting Ljubljana with Köln and Munich in Germany. In 1989 established company YuCombi, later renamed into Adria kombi ltd., has a wide spread network of trains transporting containers, semi-trailers and swap bodies to 72 terminals in Europe and currently offers nine specialized services both in domestic and in international traffic. In addition, they also provide tailored services for automobile industry and the industry of fast moving consumer goods.

In 2017, around 5 million tons of cargo were transported in combined transport in Slovenia (SŽ, 2018), mainly sourcing or sinking in the Port of Koper, the only Slovenian international cargo port. The Table 1 shows main origins and destinations for combined transport in Slovenia. 
Table 1

International Combined Transport from and to Slovenia in 2016

\begin{tabular}{|c|c|c|c|c|}
\hline & $\begin{array}{c}\text { From Slovenia } \\
(1,000 \text { TEU })\end{array}$ & $\begin{array}{c}\text { To Slovenia } \\
(1,000 \text { TEU })\end{array}$ & $\begin{array}{c}\text { From Slovenia } \\
(1,000 t)\end{array}$ & $\begin{array}{c}\text { To Slovenia } \\
(1,000 t)\end{array}$ \\
\hline Austria & 8.09 & 49.55 & 78.89 & 675.84 \\
\hline Belgium & & 1.00 & & 11.20 \\
\hline Bosnia and Herzegovina & 0.01 & 0.01 & 0.11 & 0.01 \\
\hline Croatia & 0.63 & 0.86 & 4.72 & 5.99 \\
\hline Czech r. & 25.52 & 25.96 & 181.10 & 228.08 \\
\hline Finland & & 0.03 & & 0.28 \\
\hline Germany & 10.64 & 15.17 & 44.32 & 258.83 \\
\hline Greece & & 0.10 & & 0.20 \\
\hline Hungary & 64.12 & 115.10 & 643.28 & 954.16 \\
\hline Italy & 2.84 & & 4.32 & \\
\hline Luxembourg & 0.01 & & 0.07 & \\
\hline Macedonia & 0.03 & & 0.09 & \\
\hline Netherlands & & 1.86 & & 23.27 \\
\hline Norway & 0.02 & & 0.08 & \\
\hline Serbia & 0.19 & 0.21 & 1.88 & 0.36 \\
\hline Slovak r. & 65.44 & 193.48 & 446.93 & $1,440.44$ \\
\hline Sweden & & 1.15 & & 11.49 \\
\hline Total & 177.5 & 404.48 & $1,405.79$ & $3,610.15$ \\
\hline
\end{tabular}

Source: (UIC, 2017)

Besides Adria Kombi, also Kombiverkehr and Ökombi provide combined transport services; however, Adria Kombi remains major provider of these services in Slovenia. While the importance of accompanied traffic is in decline since 2009 (the amount of units transported was actually 6\% lower in 2017 than it was in 2001), the other services, namely un-accompanied and domestic intermodal transport have increased by 854 and $764 \%$, to reach almost 170,000 and 50,000 transported TEUs respectively.

\section{Policy Support for Intermodal Transport in EU and Slovenia}

The objective of European transport policy is to develop basis for optimal combination of transport services into one single product that uses efficient and cost-effective integrated transport and where competition between transport operators remains open (CEC, 1997). The European goal is also to shift $30 \%$ of road freight on longer distances (over $300 \mathrm{~km}$ ) to alternative transport modes 
by 2030 , and more than $50 \%$ by 2050 (EC, 2011). The solution that stands out, but has not yet been exploited in its full potential, is the intermodal transport.

Intermodal policy framework is based on intermodal loading unit (ILU), infrastructure development and modal shift, liberalization and competition, innovation research and development as well as on internalization of external costs (Pekin, 2010).

Intermodal or combined transport was first systematically addressed by the Directive 75/130/EEC of February 1975. This Directive established common rules for certain types of combined road/rail carriage of goods between Member States and was later on several times amended. In 1992, it was recast into the Directive 92/106/EEC. Its latest amendments have been considered in July 2018.

Intermodal transport requires support on European level in terms of adequate transport infrastructure, which is supported by compatible technologies and unified procedures. Intermodal transport is getting it in the form of Trans European Transport Network (TEN-T) and the European Rail Traffic Management system (ERTMS) which, once deployed (it has to be fully deployed on core network by 2030), will increase the capacity of existing lines by allowing higher speeds, assure lower production, operational as well as maintenance costs, and enhance cross-border interoperability. In this way, the rail sector will become more reliable and competitive.

Four railways packages have been adopted since 2001, with the goal to make the rail system liberalized and non-discriminatory for non-national rail operators as well as more competitive in regards to other transport modes. The last one, the Fourth Railway Package that was adopted in 2016 consists of four core aims, including cutting administrative costs for railway operators and simplifying market entry while strengthening the role of infrastructure managers. The package is divided into two pillars, technical and market pillar. Within technical pillar, two directives, namely Directive 2008/57/EC on interoperability of rail system and Directive 2004/49/EC on railway safety, have been recast to Directive (EU) 2016/797 and Directive (EU) 2016/798 respectively. Member states needed to transpose both directives into national legislation by 16 th of June 2019 , with an option to request an extension of up to a year. In addition, some other directives that do not directly affect the rail or intermodal transport, but can have indirect impact, like for example Directive 96/53/EC regarding weights and dimensions of commercial road vehicles or Eurovignette Directive, have been refreshed. Last but for sure not least, the long-time discussed internalization of external costs of transport as well as fair and efficient pricing, once arranged, would give significant wind in the back to more extensive use of intermodal transport.

The company Ecorys developed the online portal Intermodal links in May 2013 to provide information for potential users on the available intermodal services. The database is constantly growing, and currently the portal delivers accurate schedules of 160 intermodal operators providing services between around 1,000 intermodal terminals (de Langen et. al, 2017; Intermodal Links, 2019). However to become more competitive and widely used, the intermodal transport must be promoted through the policies 
at all political levels (Macharis, 2011), including national. Some Member states have established active policies to promote intermodal transport (Pedersen, 2009). For example, in some states restrictions for heavy good vehicles exists over the weekends, some increase the fuel price or the toll prices, while others provide national funding measures and programmes for combined transport. These measures include funding of combined transport operations, the infrastructure, the suprastructure and equipment, research and fiscal support (summarized from UIC, 2019).

Slovenia has signed several agreements related to the intermodal transport; for example European Agreement on important international combined transport lines and related installations (AGTC Agreement), the Alpine convention, or the Convention concerning International Carriage by Rail (COTIF).

Two TEN-T corridors (Baltic Adriatic and Mediterranean corridor), and four rail freight corridors (RFC) corridors (RFC 5 - Baltic Adriatic, RFC 6 - Mediterranean, RFC 10 Alpine-Western Balkan and RFC 11 - Amber corridor) cross Slovenia. In addition, ten locations in Slovenia offer multiple logistic terminals and storage facilities (Figure 1); five of them are important for combined sea-road-rail transport. Those are the port of Koper (sea-road, sea-rail), Ljubljana (roadrail), Celje (road-rail), Maribor (road-rail) and Sežana (road-rail).

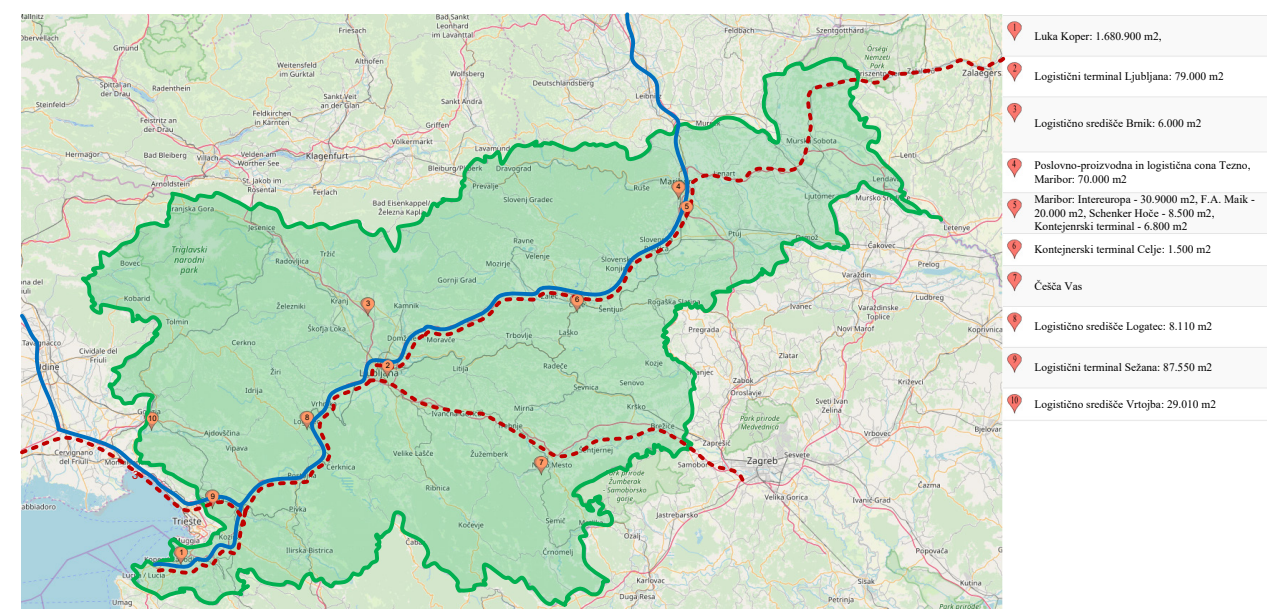

Fig. 1.

TEN-T Corridors and Logistics Terminals in Slovenia

Source: based on Zanne et al., 2019

The Slovenian transport policy from 2006 stated that intermodal transport would be supported through an appropriate fiscal policy. Nevertheless, there are no fiscal incentives for domestic haulage carriers involved in combined transport (Ur. 1. RS $23 / 2018$ ). On the other hand, there are some fiscal exemptions for carriers from non-EU countries if such carriers carry the cargo to or from the Port of Koper and do not 
perform any additional cargo manipulations in Slovenia or if they use the piggyback transport and road haulage only in feeder or final delivery carriage. This is in line with the Directive 92/106/EEC on combined transport.

The funds obtained from the annual duty for the use of road vehicles are no longer strictly aimed to the roads. In fact, from 2010 to June 2012 , those funds were redirected into the modernization of railway infrastructure, and according to the last Act on the provision of funds for investment in transport infrastructure, these funds, together with the funds collected from the concession fee of Luka Koper, are put into joint transport infrastructure budget.

Although European Commission generally does not support subsidies in transport, subsidies for the advancement of rail infrastructure and rolling stock are possible. In Slovenia, state compensation can be given to cover a part of the funds spent by combined transport operators for investments, research as well as for a part of the cost of transport, which represent special interest of the state (Ur. 1. RS 108/2000).

The Order on road traffic restrictions in the Republic of Slovenia (Ur. 1. RS 75/2011) banishes freight vehicles from the roads on Sundays and holidays from $8 \mathrm{am}$ to $9 \mathrm{pm}$ and during the tourist season on Saturdays from $8 \mathrm{am}$ to $1 \mathrm{pm}$. This limitation is not in applicable to the vehicles carrying perishable goods, and also for vehicles that are used in combined transport.
Road freight vehicles that are employed in combined transport, are permitted to have maximum authorized mass of 44 tons but only while routing towards the nearest railway terminal or port, while all other road freight vehicles are limited to a maximum weight of 40 tons (Ur. 1. RS 4/2001). In addition, the Rules on restricted use of national roads for the transport of heavy goods vehicles with a maximum authorized mass exceeding 7.5 tons (Ur. 1. RS 102/2006) require the use of the higher-level state roads when existing parallel to the roads passing through the settlements for the heavy freight vehicles. This increases the costs of road transport.

Slovenian tolling system for vehicles with maximum authorized mass of more than 3.5 tons is differentiated by vehicle type (number of axes), Euro emission standard and distance travelled. The electronic tolling system, which was set up in April 2018 prevents skipping the toll payment, which was earlier common.

In addition, starting from January the $1^{\text {st }}$ 2019 and lasting until the end of 2052, the additional charge in form of $15 \%$ of the weighted average of infrastructure fee, is used on Primorska section of A1 motorway, while on Štajerska section an extra 5\% is applied as can be seen from Table 2. In percentage change, this actually means that cleaner vehicles are penalized more than older and dirtier ones. The collected money will be filling up the budget for railways infrastructure construction, more precisely, the budget for the construction of second railway track connecting the Port of Koper with its hinterland. 
Table 2

Differentiated Toll Rates (VAT Excluded) on Slovenian Motorways

\begin{tabular}{|c|c|c|c|}
\hline \multicolumn{5}{|c|}{ R4 } \\
\hline & A1 - Primorska section & A1 - Štajerska section & Other motorways \\
\hline EURO VI & 0.30034 & 0.26482 & 0.25699 \\
\hline EURO EEV & 0.30034 & 0.26482 & 0.25699 \\
\hline EURO V & 0.34314 & 0.30758 & 0.29991 \\
\hline EURO IV & 0.38593 & 0.35046 & 0.34274 \\
\hline EURO 0, I, II, III & 0.47163 & 0.43610 & 0.42832 \\
\hline \multicolumn{2}{|c|}{ R3 } & A1 - Štajerska section & Other motorways \\
\hline \multicolumn{5}{|c|}{ A1 - Primorska section } & 0.12789 & 0.12357 \\
\hline EURO VI & 0.14778 & 0.12789 & 0.12357 \\
\hline EURO EEV & 0.14778 & 0.14845 & 0.14413 \\
\hline EURO V & 0.16828 & 0.16910 & 0.16478 \\
\hline EURO IV & 0.18890 & 0.21032 & 0.20592 \\
\hline
\end{tabular}

Note: Prices per kilometre are calculated in reverse from the total price for different routes attained from (DARS, 2019)

Source: (Zanne et al., 2019)

\section{Discussion}

Slovenia has important geo-strategic position in Europe and this is proved by planned infrastructures over Slovenia. The role of Slovenia will be further emphasized if the Blue banana, originally stretching from Manchester to Milan, continues to move towards eastern part of Europe. In this case, the role of the southern maritime European transport route, which provides the shortest and most efficient connection from the East towards the Central European countries through the ports of North Adriatic, will gain even greater importance. This will potentially generate extensive new freight flows to the already increasing volumes that are currently still mainly accommodated by the roads. In fact, Slovenia is crossed by thousands of heavy good vehicles daily, which already affects the traffic safety, traffic fluidity and consequently the reliability of deliveries. The last has negative effects of carriers (Fowkes et al., 2004) and on shippers (de Jong et al., 2014).
The TEN-T and RFC corridors are to be set as the only feasible and safe solution for such a growing traffic. Slovenia has postponed most of its investments (more than 60\%) into TEN-T priority projects (those mostly coincide with the corridors) to the post-2020 period (TENTec, 2018). These investments are into rail infrastructure, as the road infrastructure on corridor directions already completely complies with TEN-T requirements. This puts Slovenia in delay in respect to other countries, and Slovenia risks to be penalized in 2023 when the next detailed examination of achieved progress on TEN-T corridors is scheduled.

\section{Conclusions}

In the market economy, price is generally the dominant criteria when it comes to selection of the product and so it is with the selection of transport mode. However, the market prices in transport still do not reflect all the costs incurred, therefore the decisions on transport mode are not socially completely satisfactory. 
Rail or combined rail-road transport are thus not competitive to unimodal road transport in terms of price, and often also in terms of time required to cover the distance.

European freight transport is still mostly road based and oil dependent, which is not in line with the transport policy goals or Paris Agreement. Regardless of the growing volume of combined transport, it is still not contributing enough to the modal shift. Its further establishment requires harmonized activities around EU to construct interoperable infrastructure as well reliable information systems and feasible frame for fair and efficient pricing in transport. This is the precondition for expansion of rail and intermodal transport. In addition, the activities in each Member State are needed to support intermodal transport operators.

Majority of activities that can support the use of intermodal transport in Slovenia are indirect; mainly in some way affecting and penalizing the road operators. Probably because current rail infrastructure, on which passenger trains have the advantage over cargo trains, cannot accommodate additional traffic.

Slovenia has to concentrate on fulfilling the TEN $T$ requirements on rail corridors that cross the country; otherwise, it could lose various EU funding possibilities or even the freight flows that bring the money to the national economy. This is the only viable long-term solution; however, it is expensive and time demanding. Our further research will thus focus on the traffic structure on Slovenian railways. We will investigate rail passenger traffic in Slovenia and estimate the potential shift of freight flows from roads to rails if certain rail capacities are freed up by cancelling out the least utilized passenger trains.

\section{Acknowledgments}

The research was carried out as part of bilateral project " $T$ he development of intermodal transport, intermodal nodes and hinterland network in the eastern Adriatic region" between Slovenia and Montenegro.

\section{References}

Bektas, T.; Crainic, T. G. 2007. A brief overview of intermodal transportation. Montreal \& Quebec: CIRRELT - Interuniversity Research Centre of Enterprise Networks, Logistics and Transportation.

Bergqvist, R.; Behrends, S. 2011. Assessing the effects of longer vehicles: The case of pre- and post-haulage in intermodal transport chains, TransportReviews 31(5): 591-602.

CEC. 1997. Intermodality and intermodal freight transport in the European Union. Brussels: Commission of the European Communities.

DARS. 2019. Informativni izračun cestnine [in English: electronic tolling system]. Available from internet: $<$ https:// www.darsgo.si/portal/si/izracun >. Accessed February 2019.

de Jong, G.; Kouwenhoven, M.; Bates, J.; Koster, P.; Verhoef, E.; Tavasszy, L.; Warffemius, P. 2014. New SP-values of time and reliability for freight transport in The Netherlands, Transportation Research Part E: Logistics and Transportation Review 64: 71-87.

de Langen, P. W.; Lases Figuero, D. M.; van Donselaar, K.; Bozuwa, J. 2017. Intermodal connectivity in Europe, an empirical exploration, Research in Transportation Business \& Management 23: 3-11.

EC. 2011. Transport 2050: Commission outlines ambitious plan. Brussels: European Commission.

EC. 2016. REFIT ex-post evaluation of Combined Transport Directive (92/106/EEC) - Executive summary. Brussels: European Commission. 
EC. 2018. Statistical pocketbook 2018: Transport in figures. Luxembourg: Publications Office of the European Union.

Eurostat. 2019. Freight transport statistics - modal split. Available from internet: <https://ec.europa.eu/eurostat/ statistics-explained/index.php/Freight_transport_ statistics_-_modal_split>.

Fowkes, A. S.; Firmin, P. E.; Tweddle, G.; Whiteing, A. E. 2004. How highly does the freight transport industry value journey time reliability - and for what reasons? International Journal of Logistics 7(1): 33-43.

Intermodal Links. 2019. Available from internet: <https://intermodallinks.com>.

Macharis, C. E. 2011. A decision support framework for intermodal transport policy, European Transport Research Review 3: 167-178.

Pedersen, J. T. 2009. Promoting Innovative Intermodal Freight Transport. LogIT.

Pekin, E. 2010. Intermodal Transport Policy: A GIS-based Intermodal Transport Policy Evaluation Model. Brussels: Vrije Universiteit Brussel: Faculty of economics, social and political sciences and Solvay business school.

Seidelmann, C. 2010. 40 years of road-rail combined transport in Europe. Brussels: International Union of combined Road-Rail transport companies.

SŽ. 2018. Annual report 2017. Ljubljana: Slovenian railways.

TENTec. 2018. Trans European Transport Network - Key facts. Available from internet: <http://ec.europa.eu/ transport/infrastructure/tentec/tentec-portal/site/ en/keyfacts.html>.

Transport \& Environment. 2017. Roadmap to climatefriendly land freight and buses in Europe. Brussels: European Federation for Transport and Environment AISBL.
UIC. 2017. 2016 report on Combined transport in Europe. Paris: International Union of Railways. Available from internet: <https://uic.org/IMG/pdf/2016_report_on_ combined_transport_in_europe_cles.pdf $>$.

UIC. 2019. 2018 Report on combined transport in Europe. Paris: International Union of Railways. Available from internet: <https://uic.org/IMG/pdf/2018_report_on_ combined_transport_in_europe.pdf $>$.

Ur. 1. RS 108/2000. Uredba o nadomestilu dela stroškov za prevoze, raziskave in naložbe prevoznikom, ki opravljajo določene prevozne storitve v železniškem prometu [In English: Decree on partial compensation for the costs of transport services, research and investments in respect of railway undertakings which provide specific transport services in railway transport]. Uradni list Republike Slovenije.

Ur. 1. RS 4/2001. Uredba o kombiniranem prevozu [In English: Decree on combined transport]. Uradni list Republike Slovenije.

Ur. 1. RS 102/2006. Pravilnik o omejitvi uporabe državnih cest za promet tovornih vozil, katerih največja dovoljena masa presega 7,5 ton [In English: Rules on restricted use of national roads for the transport of heavy goods vehicles with a maximum authorised mass exceeding 7.5 tons]. Uradni list Republike Slovenije.

Ur.1. RS 75/2011. Odredba o omejitvi prometa na cestah v Republiki Sloveniji [In English: Order on road traffic restrictions in the Republic of Slovenia]. Uradni list Republike Slovenije.

Ur.1. RS 23/2018. Uredba o letni dajatvi za uporabo vozil $\mathrm{v}$ cestnem prometu [In English: Decree on the annual road tax]. Uradni list Republike Slovenije.

Zanne, M.; Krmac, E.; Bajec P.; Škerlič S. 2019. Model prometne politike $v$ funkciji trajnostnega razvoja Republike Slovenije in Republike Makedonije [In English: Model of transport policy in the function of sustainable development of the Republic of Slovenia and the Republic of Macedonia]. Fakulteta za pomorstvo in promet, Portorož, Slovenia. 